Vol I. No. 1, Mei 2012, hlm. 85 - 92

\title{
PERBEDAAN HASIL BELAJAR MATEMATIKA SISWA YANG DIBERI UMPAN BALIK BERUPA ANGKA SAJA DENGAN UMPAN BALIK BERUPA ANGKA DISERTAI KOMENTAR
}

\author{
Andy Sapta \\ Universitas Asahan \\ e-mail: saptaandy@gmail.com
}

\begin{abstract}
This study aims to see the differences in mathematics learning outcomes of students who were given feedback in the form of numbers only with numeric feedback with comments in class XII Sains of Harapan Senior High School Medan and to find out what mathematics learning outcomes better than both. Average scores with post-test feedback in the form of numbers alone are 13.800 (average value 69) with the highest score of 19 (highest score 95) and the lowest score of 10 (the lowest value 50) for the control class, while the average score post-test by giving feedback in the form of numbers with comments is 15.025 (75.125 average value) with the highest score of 20 (highest score 100) and the lowest score of 12 (the lowest value 60) for the experimental class. This means that $\mathrm{Ha}$ received student achievement by providing feedback in the form of numbers with comments is better than giving feedback in the form of numbers only in class XII Sains of Harapan Senior High School Medan School Year 2011/2012.
\end{abstract}

Keywords: feedback, comments

\begin{abstract}
Abstrak
Penelitian ini bertujuan untuk melihat perbedaan hasil belajar matematika siswa yang diberi umpan balik hanya berupa angka dengan umpan balik dengan komentar di kelas XII IPA Harapan SMA Medan dan untuk mengetahui mana hasil belajar matematika lebih baik daripada keduanya. Skor rata-rata dengan umpan balik post-test hanya berupa angka adalah 13.800 (nilai rata-rata 69) dengan skor tertinggi 19 (skor tertinggi 95) dan skor terendah 10 (nilai terendah 50) untuk kelas kontrol, sedangkan skor rata-rata post-test dengan memberikan umpan balik berupa angka dengan komentar adalah 15.025 (75.125 nilai rata-rata) dengan skor tertinggi 20 (skor tertinggi 100) dan skor terendah 12 (nilai terendah 60) untuk kelas eksperimen. Artinya, Ha diperoleh hasil belajar siswa dengan memberikan umpan balik berupa angka dengan komentar lebih baik daripada memberi umpan balik hanya berupa angka di kelas XII IPA Harapan SMA Medan Medan Tahun 2011/2012.
\end{abstract}

Kata kunci: umpan balik, komentar 
Pendidikan adalah investasi jangka panjang yang harus ditata, disiapkan, dan diberikan sarana maupun prasarananya dalam arti modal material yang cukup besar. Pendidikan juga memegang peranan penting bagi kemajuan suatu bangsa dan negara. Demikian halnya dengan Indonesia yang menaruh harapan besar terhadap pendidikan dalam perkembangan masa depan bangsa ini. Sebab dari pendidikanlah akan dibentuk generasi-generasi penerus bangsa.

Sampai saat ini Indonesia masih berkutat pada problematika (masalah) klasik, yang dalam hal ini adalah kualitas pendidikan. Problematika ini sudah dicoba untuk dicari akar permasalahannya, akan tetapi sampai sekarang hal tersebut masih belum ditemukan solusi pemecahannya.

Matematika adalah salah satu mata pelajaran yang sangat penting untuk dipelajari oleh peserta didik (siswa). Selain matematika yang dianggap sebagai ratunya ilmu, matematika juga termasuk dalam mata pelajaran yang termasuk

dalam ujian nasional. Alasan pentingnya pelajaran matematika adalah kemampuan siswa dalam bermatematika merupakan landasan pokok pola pikir yang menjadi syarat mutlak yang harus dikuasai untuk melatih siswa agar dapat berpikir dengan jelas, logis, teratur, sistematis, bertanggung jawab, memiliki kepribadian yang baik, dan keterampilan untuk menyelesaikan persoalan dalam kehidupan seharihari.

Sampai saat ini pelajaran matematika merupakan salah satu pelajaran yang tidak disukai oleh siswa. Penyebab siswa tidak menyukai pelajaran matematika antara lain seperti anggapan bahwa ilmu pasti itu sulit, rumit, membingungkan, dan membuat kepala menjadi pusing. Setiap materi pada pelajaran matematika pasti memiliki rumus masing-masing, sehingga dalam pelajaran matematika akan banyak sekali dijumpai rumus-rumus. Selain itu meskipun sudah hapal rumusnya belum menjadi jaminan bisa mengerjakan soal matematika. Hal ini dapat dibuktikan pada hasil belajar matematika siswa yang masih sangat rendah.

Seringkali guru memberikan latihan-latihan yang terlalu banyak, dan menyuruh siswa berdiri di depan kelas sebagai hukuman karena tidak mengerjakan latihan-latihan tersebut. Padahal bisa saja alasan siswa tidak mengerjakan latihan-latihan itu karena guru tidak memberikan umpan balik (feed back) yang baik terhadap siswa tersebut. Dari hasil wawancara peneliti dengan guru matematika di SMA Harapan Medan, diperoleh informasi bahwa siswa-siswa yang mengerjakan latihan hanya diberikan umpan balik berupa angka, dan tidak ada komentar guru secara tertulis. Umpan balik yang dilakukan guru juga sering terlambat.

Guru seharusnya memberikan umpan balik terhadap tugas, latihan soal, PR, ulangan harian, dan lain sebagainya yang telah dikerjakan oleh siswa. Umpan balik dapat juga berupa perkataan, misalnya untuk proses pembelajaran maupun terhadap hasil belajar yang mereka lakukan atau yang telah mereka capai dengan baik. Bisa pula berupa kritikan yang bersifat membangun motivasi belajar dan perbaikan proses atau pencapaian hasil belajar tadi.

Sangat disayangkan bila seorang guru tidak memberikan umpan balik terhadap pekerjaan siswa. Terutama kaitannya dalam peng- 
koreksian pada kertas kerja siswa. Guru yang tidak memberikan umpan balik dalam bentuk koreksi kertas kerja siswa sangat merugikan dan merusak motivasi belajar siswa. Guru yang malas mengkoreksi hasil pekerjaan siswa membuat siswa menunggu-nunggu. Tidak jarang siswa menjadi kesal terhadap guru, bahkan harus menagih kepada guru tentang kertas kerja mereka. Akhirnya, beberapa siswa cenderung akan kehilangan keinginan untuk melihat nilai yang mereka peroleh dari hasil latihan yang telah mereka kerjakan itu. Sesuai dengan Peraturan Pemerintah salah satu tugas guru yang baik dan profesional adalah memberikan penilaian kepada siswa. Penilaian bisa berupa umpan balik dalam bentuk koreksian pekerjaan siswa. Hasil koreksian tersebut sebenarnya sangat bermanfaat, tidak hanya bagi siswa, tetapi juga bagi guru. Analisis kelemahan dan kekuatan sebuah pembelajaran dapat dilakukan berdasarkan hasil pekerjaan siswa. Selanjutnya hasil analisis dapat dijadikan dasar pijakan untuk perencanaan dan pelaksanaan pembelajaran berikutnya. Pembelajaran yang berdasarkan analisis semacam ini akan berbuah menjadi pembelajaran yang efektif, efisien, dan menyenangkan bagi siswa dan guru.

Pemberian umpan balik berupa koreksi dan pengembalian kertas kerja hasil pekerjaan siswa yang terlalu lama juga menyebabkan guru mengalami kesulitan memberikan reviu terhadap materi penting, yang barangkali akhirnya akan diketahui berdasarkan hasil analisis kertas kerja siswa tersebut bahwa siswa belum menguasai materi dengan baik. Lamanya rentang antara waktu koreksi dan pengembalian itulah maka materi yang tidak dikuasai dengan baik oleh siswa jadi begitu jauh terlewatkan.

Adapun yang menjadi rumusan masalah dalam penelitian ini adalah: (1) Apakah ada perbedaan hasil belajar matematika siswa yang diberi umpan balik berupa angka saja dengan umpan balik berupa angka disertai komentar di kelas XII IPA SMA Harapan Medan? (2) Manakah hasil belajar matematika yang lebih baik pada siswa yang diberi umpan balik berupa angka saja dengan umpan balik berupa angka disertai komentar di kelas XII IPA SMA Harapan Medan?

Adapun tujuan penelitian ini adalah untuk mengetahui: (1) Perbedaan hasil belajar matematika siswa yang diberi umpan balik berupa angka saja dengan umpan balik berupa angka disertai komentar di kelas XII IPA SMA Harapan Medan; (2) Hasil belajar matematika yang lebih baik pada siswa yang diberi umpan balik berupa angka saja dan dengan umpan balik berupa angka disertai komentar di kelas XII IPA SMA Harapan Medan.

Penelitian ini diharapkan dapat bermanfaat sebagai berikut: (1) Sebagai bahan informasi dan masukan bagi guru matematika tentang cara yang tepat dalam memberikan umpan balik dari kertas kerja siswa; (2) Sebagai bahan pertimbangan bagi guru matematika agar lebih dapat meningkatkan pemberdayaan pemberian umpan balik yang disertai dengan komentar, agar hasil belajar matematika siswa lebih baik; (3) Sebagai bahan masukan bagi siswa untuk memanfaatkan latihan-latihan yang diberikan oleh guru dalam rangka meningkatkan hasil belajarnya; (4) Sebagai informasi dan masukan bagi kepala sekolah dalam mengambil kebijakan untuk mengelola pemberian 
umpan balik yang dilakukan guru matematika.

Menurut Roojakkers (dalam Suhadi, 2006) umpan balik hanya dimaksudkan untuk mencari informasi sejauh mana siswa mengerti bahan yang telah dibahas. Selain itu siswa juga diberi kesempatan untuk memeriksa diri sampai dimana mereka mengerti bahan tersebut. Sehingga mereka dapat melengkapi pengertianpengertian yang belum lengkap.

Beberapa bentuk umpan balik yang dapat diberikan guna mempertahankan motivasi siswa terhadap bahan pelajaran yang diberikan antara lain sebagai berikut:

1. Memberikan Hadiah

Hadiah adalah sesuatu yang diberikan kepada orang lain sebagai penghargaan atau kenangkenangan/cenderamata.

Pemberian hadiah bisa diterapkan di sekolah. Guru dapat memberikan hadiah kepada siswa yang berprestasi. Keampuhan hadiah sebagai alat untuk memberikan umpan balik kepada siswa akan terasa jika penggunaannya tepat. Namun demikian memberikan hadiah terlalu sering tidak dibenarkan, sebab hal itu akan menjadi kebiasaanyang kurang menguntungkan kegiatan belajar mengajar. Renate dalam Kaufeld (2008) mengatakan bahwa hadiah-hadiah untuk hasil belajar yang spesifik mendorong siswa untuk memusatan perhatian secara sempit pada sebuah tugas, mengerjakannya secepat mungkin, tidak memperhatikan informasi lainnya, dan mengambil beberapa resiko.

2. Gerakan Tubuh

Gerakan tubuh merupakan penguatan yang dapat membang- kitkan gairah belajar anak didik, sehingga proses belajar mengajar lebih menyenangkan. Gerakan tubuh dalam bentuk mimik yang cerah, acungan jempol, tepuk tangan, memberi salam, menaikkan bahu, menggeleng-gelengkan kepala, menaikkan tangan, dan lain-lain adalah sejumlah gerakan fisik yang dapat memberikan umpan balik bagi siswa.

3. Memberikan Angka

Angka yang dimaksudkan di sini adalah sebagai simbol atau nilai dari hasil aktivitas belajar siswa. Angka merupakan alat motivasi yang cukup memberikan rangsangan kepada siswa untuk mempertahankan atau bahkan lebih meningkatkan hasil belajar mereka. Apabila angka yang diperoleh siswa lebih tinggi dari siswa yang lainnya, maka siswa cenderung untuk mempertahankannya. Namun guru dituntut untuk tidak memberikan angka penilaian yang sembarangan, sehingga tidak merugikan siswa yang betul-betul belajar. Jika tidak, maka siswa akan merasa kecewa atas sikap guru dan kemungkinan besar guru akan dibenci oleh siswa yang merasa dirugikan.

4. Pujian atau Komentar

Pujian adalah alat motivasi yang positif. Orang yang dipuji merasa bangga karena hasil kerjanya mendapat pujian dari orang lain. Kata-kata "kerjamu bagus", "kerjamu rapi", dan sebagainya adalah sejumlah kata-kata yang biasanya digunakan orang lain untuk memuji orang-orang tertentu yang dianggap berprestasi. Pujian yang baik adalah pujian yang keluar dari hati seorang guru secara wajar dengan maksud 
untuk memberikan penghargaan kepada siswa atas jerih payahnya dalam belajar.

\section{METODE}

Populasi dalam penelitian ini adalah seluruh siswa kelas XII IPA SMA Harapan Medan yaitu sebanyak 5 kelas yang seluruhnya berjumlah 180 orang. Sampel dalam penelitian ini adalah 2 kelas dari seluruh siswa kelas XII IPA SMA Harapan Medan. Sampel dipilih secara acak (random) sehingga memberikan kemungkinan yang sama bagi setiap kelas untuk dipilih menjadi sampel. Dengan cara melakukan undian maka terpilih yang menjadi sampel adalah kelas XII IPA 5 untuk pemberian umpan balik berupa angka dan kelas XII IPA 1 untuk pemberian umpan balik berupa angka disertai komentar. Masingmasing kelas berjumlah 40 orang.

Penelitian ini memiliki dua variabel yaitu variabel bebas dan variabel terikat. Variabel penelitian tersebut adalah sebagai berikut: (1) Variabel bebas (independent variabel) yaitu: pemberian umpan balik dengan cara pemberian angka saja dan dengan pemberian angka disertai komentar; (2) Variabel terikat (dependent variabel) yaitu hasil belajar matematika siswa.

Instrumen penelitian sebagai alat pengumpul data, digunakan tes yaitu tes yang berbentuk objektif pilihan berganda sebanyak 10 soal yang disusun sesuai dengan kurikulum dan tujuan pengajaran yang telah ditentukan. Setiap butir soal disediakan lima pilihan jawaban yang diantaranya terdapat satu jawaban yang benar. Sebelum tes diujikan kepada sampel, peneliti terlebih dahulu engujicobakan tes ke sekolah lain sebanyak satu kali untuk melihat validitas, reliabilitas, tingkat kesukaran soal, dan daya pembeda tes.

\section{HASIL}

Sebelum melakukan evaluasi dengan pemberian umpan balik yang berbeda yaitu pemberian umpan balik berupa angka saja pada kelas kontrol dan pemberian umpan balik berupa angka yang disertai komentar pada kelas eksperimen, terlebih dahulu diberikan pre-test (tes awal) yang bertujuan untuk mengetahui kemampuan awal siswa kedua kelas. Siswa yang mengikuti pre-tes untuk kelas eksperimen dan kelas kontrol masingmasing berjumlah 40 orang. Dari hasil pemberian pre-tes diperoleh skor ratarata hasil belajar siswa kelas eksperimen adalah 11,300 dan dari hasil pemberian pre-tes diperoleh skor rata-rata hasil belajar siswa kelas kontrol adalah 11,375.

Dengan pengujian kesamaan dua rata-rata (uji hipotesis) dari data pre-tes yang diperoleh pada kelas eksperimen dan kelas kontrol diperoleh bahwa kemampuan awal siswa pada kedua sampel adalah sama. Setelah diberikan pre-tes pada kedua kelas dan diperoleh tidak ada perbedaan kemampuan awal siswa, maka dilakukan pembelajaran dengan pemberian umpan balik yang berbeda, yaitu pada kelas kontrol pemberian umpan balik berupa angka saja dan pada kelas eksperimen pemberian umpan balik berupa angka yang disertai dengan komentar. Dengan dilakukannya pembelajaran dengan pemberian umpan balik yang berbeda diperoleh hasil belajar siswa. Dari hasil pemberian post-tes diperoleh skor rata-rata hasil belajar kelas control adalah 13,800 dan dari hasil 
pemberian post-tes diperoleh skor rata-rata hasil belajar siswa kelas eksperimen adalah 15,025.

Dari hasil pemberian post-tes, diperoleh perbedaan hasil belajar siswa yang berarti dimana kelas eksperimen yang pembelajarannya diberikan umpan balik berupa angka yang disertai komentar hasilnya lebih baik dibandingkan dengan hasil belajar siswa pada kelas kontrol yang pembelajarannya diberikan umpan balik hanya berupa angka saja.

Pengujian normalitas data dilakukan dengan Uji Lilliefors yakni untuk mengetahui apakah data berdistribusi normal atau tidak. Syarat normal dipenuhi apabila $L_{\text {hitung }}<L_{\text {tabel }}$ pada taraf nyata $\alpha=0,05$. Uji normalitas pada data pre-tes kelas kontrol diperoleh $L_{\text {hitung }}(0,1293)<$ $L_{\text {tabel }}(0,1401)$, dan data pre-tes kelas eksperimen diperoleh $L_{\text {hitung }}(0,1386)$ $<L_{\text {tabel }}(0,1401)$. Sedangkan data posttes kelas kontrol diperoleh $L_{\text {hitung }}$ $(0,1272)<L_{\text {tabel }}(0,1401)$ dan data post-tes kelas eksperimen diperoleh $L_{\text {hitung }}(0,1364)<L_{\text {tabel }}(0,1401)$ pada taraf nyata $\alpha=0,05$. dengan demikian dapat disimpulkan bahwa data pada kedua kelompok sampel berdistribusi normal.

Untuk menguji apakah kedua sampel memiliki varians yang homogen, digunakan uji kesamaan varians. Dari hasil perhitungan uji homogenitas pre-tes diperoleh $F_{\text {hitung }}=$ 1,068 dan $F_{\text {tabel }}$ pada $\alpha=0,05$ dan dk $\mathrm{v}_{1}=\mathrm{n}_{1}-1$ dan $\mathrm{v}_{2}=\mathrm{n}_{2}-1$ diperoleh $F_{(0,05)(39,39)}=1,704$. Sehingga diperoleh $F_{\text {hitung }}(1,068)<F_{\text {tabel }}$ $(1,704)$ yang berarti data pre-tes memiliki varians yang homogen.

Untuk data post-tes diuji kesamaan variansnya dan diperoleh $F_{\text {hitung }}=1,02$ dan $F_{\text {tabel }}$ pada $\alpha=0,05$ dan $\mathrm{dk} \mathrm{v}_{1}=\mathrm{n}_{1}-1$ dan $\mathrm{v}_{2}=\mathrm{n}_{2}-1$ diperoleh $F_{(0,05)(39,39)}=1,704$, sehingga diperoleh $F_{\text {hitung }}(1,02)<F_{\text {tabel }}(1,704)$ yang berarti data post-tes memiliki varians yang homogen.

Sebelum diberikan umpan balik kepada kedua sampel, dari hasil perhitungan hipotesis diperoleh kesimpulan bahwa tidak ada perbedaan yang berarti kemampuan awal (pre-tes) siswa kedua sampel dengan harga $t_{\text {hitung }}(0,179)<t_{\text {tabel }}$ $(1,667)$.

Setelah dilakukan pembelajaran dengan pemberian umpan balik yang berbeda yaitu kelas kontrol dilakukan pemberian berupa angka saja sedangkan pada kelas eksperimen diberikan umpan balik berupa angka yang disertai komentar . Hasil perhitungan hipotesis diperoleh harga $t_{\text {hitung }}=2,42$, selanjutnya pada taraf signifikan $\alpha=0,05$ dan $\mathrm{dk}=40+40-$ $2=78$ didapat harga $t_{\text {tabel }}=1,667$. Dengan membandingkan harga $t_{\text {hitung }}$ dan $t_{\text {tabel }}$ diperoleh bahwa $t_{\text {hitung }}(2,42)$ $<\mathrm{t}_{\text {tabel }}(1,667)$ maka tolak $H_{0}$ atau terima $H_{a}$ sehingga disimpulkan ada perbedaan yang berarti antara hasil belajar siswa yang diberikan umpan balik berupa angka saja dan hasil belajar siswa yang diberikan umpan balik berupa angka yang disertai komentar di kelas XII IPA SMA Harapan Medan Tahun Ajaran 2011/2012.

\section{PEMBAHASAN}

Setelah tes diuji cobakan kepada 40 orang siswa diperoleh 20 soal dinyatakan valid dan keseluruhan soal dinyatakan reliabel. Berdasarkan tingkat kesukaran soal diperoleh 2 soal kategori mudah dan 18 soal kategori sedang. Berdasarkan daya pembeda tes diperoleh 5 soal kategori jelek, 13 soal kategori cukup dan 2 soal kategori baik. 
Pada awal penelitian ini diberikan pre-tes kepada kelas kontrol dan kelas eksperimen. Diperoleh skor rata-rata kelas kontrol 11,375 (nilai rata-rata 56,875) dengan skor tertinggi 17 (nilai tertinggi 85) dan skor terendah 8 (nilai terendah 40), serta kelas eksperimen memperoleh skor rata-rata 11,300 (nilai rata-rata 56,500) dengan skor tertinggi 15 (nilai tertinggi 75) dan skor terendah 7 (nilai terendah 35). Dari hasil pre-tes terlihat bahwa hasil belajar siswa sebelum diterapkan pembelajaran dengan pemberian umpan balik tergolong homogen.

Berdasarkan hasil penelitian uji homogenitas data pre-tes tidak terdapat perbedaan kedua varians atau kedua sampel homogen dimana $F_{\text {hitung }}(1,068)<F_{\text {tabel }}(1,704)$ sedangkan untuk data post-tes diperoleh $F_{\text {hitung }}(1,02)<F_{\text {tabel }}(1,704)$ yang berarti data post-tes memiliki varians yang homogen juga. Sehingga dapat disimpulkan bahwa data pre-tes dan data post-tes memiliki varians yang homogen.

Dari hasil analisis data pre-tes diperoleh nilai $L_{0}=0,1293$ untuk kelas kontrol dan $L_{0}=0,1386$ untuk kelas eksperimen. Sedangkan untuk data post-tes diperoleh $L_{0}=0,1272$ untuk kelas kontol dan $L_{0}=0,1364$ untuk kelas eksperimen. Nilai-nilai $L_{0}$ tersebut lebih kecil dari nilai $\mathrm{L}_{\text {tabel }}$ yaitu 0,1401 sehingga disimpulkan bahwa data berdistribusi normal.

Berdasarkan hasil pemberian post-tes pada kedua kelas diperoleh skor rata-rata post-tes dengan pemberian umpan balik berupa angka saja adalah 13,800 (nilai rata-rata 69) dengan skor tertinggi 19 (nilai tertinggi 95) dan skor terendah 10 (nilai terendah 50) untuk kelas kontrol, sedangkan skor rata-rata posttes dengan pemberian umpan balik berupa angka yang disertai komentar adalah 15,025 (nilai rata-rata 75,125 ) dengan skor tertinggi 20 (nilai tertinggi 100) dan skor terendah 12 (nilai terendah 60) untuk kelas ekaperimen. Sehingga terlihat bahwa pencapaian hasil belajar siswa dengan pemberian umpan balik berupa angka yang disertai komentar lebih baik dibandingkan dengan pemberian umpan balik yang berupa angka saja di kelas XII IPA SMA Harapan Medan Tahun Ajaran 2011/2012.

Hal ini disebabkan antara lain: (1) Melalui pemberian umpan balik berupa angka yang disertai komentar siswa lebih mengetahui kelemahan diri mereka sendiri sehingga mereka mampu memperbaikinya untuk pencapaian hasil belajar yang lebih baik; (2) Bagi guru matematika merupakan kesempatan untuk melatih diri memegang tanggung jawab dalam mengemban tugas dan melatih kesabaran; (3) Melalui pemberian umpan balik berupa angka yang disertai komentar siswa lebih merasa diperhatikan oleh guru.

Namun disamping kelebihan dari teknik pemberian umpan balik berupa angka yang disertai komentar, teknik ini juga memiliki kelemahan antara lain: (1) Komentar kepada siswa yang kurang memotivasi membuat siswa menjadi kurang bersemangat untuk menyelesaikan tugas dengan baik; (2) Guru tidak mengenal satu persatu siswanya sehingga sulit untuk memberikan komentar yang sesuai dengan kepribadian individu siswa.

\section{SIMPULAN DAN SARAN}

Dari hasil analisis data post-tes kelompok yang diberikan umpan balik berupa angka saja dengan pemberian umpan balik yang disertai komentar 
maka diperoleh kesimpulan sebagai berikut: (1) Terdapat perbedaan hasil belajar matematika siswa yang diberikan umpan balik berupa angka saja dengan pemberian umpan balik berupa angka yang disertai komentar di kelas XII IPA SMA Harapan Medan; (2) Pencapaian hasil belajar matematika siswa dengan pemberian umpan balik berupa angka yang disertai komentar lebih baik atau lebih tinggi dibandingkan dengan hasil belajar matematika siswa yang diberikan umpan balik berupa angka saja.

Berdasarkan pembahasan dan kesimpulan yang telah dikemukakan, maka disarankan sebagai berikut: (1) Bagi guru khususnya guru matematika diharapkan untuk dapat menerapkan pemberian umpan balik berupa angka yang disertai komentar untuk

\section{DAFTAR RUJUKAN}

Arikunto, S. 2002. Dasar-dasar Evaluasi Pendidikan. Jakarta: Bumi Aksara.

Kaufelt, M. 2008. Wahai Para Guru, Ubahlah Cara Mengajarmu!. Jakarta: Indeks. mendorong siswa lebih teliti dalam mengerjakan soal-soal matematika serta sebagai alat untuk mengintrospeksi diri; (2) Bagi guru diharapkan mampu mengenali seluruh kepribadian individu siswa agar dapat memberikan komentar yang sesuai dengan siswa sehingga tumbuh motivasi positif dari dalam diri siswa; (2) Bagi mahasiswa calon guru matematika diharapkan agar dapat menerapkan pemberian umpan balik berupa angka yang disertai komentar saat memberikan penilaian dalam upaya meningkatkan hasil belajar matematika siswa: (3) Bagi pihak yang terkait seperti pihak sekolah diharapkan untuk lebih memperhatikan kelebihan dan kelemahan dari umpan balik yang diberikan kepada siswa dalam upaya meningkatkan hasil belajar matematika siswa.

Suhadi. 2006. Pentingnya Pemberian Umpan Balik dalam Pembelajaran 